\title{
ENERGY METABOLISM OF AN AMAUROTIC FAMILY IDIOT *
}

\author{
FRITZ B. TALBOT, M.D. \\ BOSTON
}

The following case of amaurotic family idiocy was obtained from the Children's Hospital through the kindness of Dr. John Lovett Morse, and studied under the direction of Dr. F. G. Benedict at the Nutrition Laboratory of the Carnegie Institution of Washington, Bostun, Mass.

\section{HISTORY OF CASE}

History.-The child, B. D., girl, aged 2 years and 4 months, was admitted to the hospital Nov. 22, 1916. The father and mother, brother and sister were living and well, and were of normal mental and physical development. There was a normal family history.

The patient was born of a normal pregnancy and labor, and was breast fed for one year, during most of which time she had a severe facial eczema. At 3 to 4 months she first noticed her hands, but never made any effort to use them except to play with a rattle, when it was placed in them. If she dropped the rattle, she was unable to find it, nor could she pick it up if her hands came in contact with it by accident. She never played with anything else, and had never been able to hold up her head or sit up.

Dec. 24,1915 , she had a convulsion during which the extremities jerked for an hour or more, the eyes were rolled up, and she perspired and drooled. In February, 1916, she entered the Infants' Hospital and Dr. George H. Derby found on examination of the eye grounds, "secondary atrophy of the optic nerve heads, and cherry-red spots in the macular regions with edema about them." She entered the Children's Hospital because she was mentally backward, could not see, and was only able to take liquid food. She took no notice of her surroundings, and lay quietly except when startled by a noise, which could cause a temporary clonic convulsion of all the extremities. Except during these periods of spasm, she lay absolutely still, without any voluntary movement.

Physical Examination. - This showed an underdeveloped, poorly-nourished child, lying quietly in bed, drooling constantly and taking no notice of the surroundings. The extremities were cold and the feet slightly blue. The head was large in proportion to the body. Both pupils reacted to light, but the right was slightly larger than the left. They were regular in outline. The physical examination otherwise revealed nothing abnormal except that the extremities were spastic and markedly atrophied. There were no signs of voluntary motion. The von Pirquet test was negative. The white count was 9,800 . The urine was acid, cloudy, straw colored and contained the slightest possible trace of albumin. The sediment contained many pus cells. Lumbar puncture, 8 c.c., clear fluid under normal pressure. Cell count 7 , of which one was a leukocyte and six were epithelial cells. The Wassermann reaction was

* Submitted for publication June 4, 1918.

* Read at the meeting of the American Pediatric Society, Lenox, Mass., May, 1918.

* From the Nutrition Laboratory of the Carnegie Institution of Washington, Boston. 
negative. From December 5 to 12 , the week preceding the time that the metabolism was observed, the child's temperature was subnormal, the lowest being $95.5 \mathrm{~F}$. At times during this period the pulse registered 69 . This was lower than the careful pulse records taken during the metabolism periods. She never cried and lay absolutely quiet in bed except when disturbed by a sudden, loud noise or by being touched. External stimuli of this sort caused clonic convulsive movements. During this period she simply existed in bed, taking her food as it was given to her. She died Dec. 26, 1916, probably of inanition as a result of pyelitis and amaurotic family idiocy.

Necropsy.-Postmortem examination by Dr. S. B. Marlow showed a few facts of importance when taken in connection with the metabolism. The body was $75 \mathrm{~cm}$. long and showed extreme emaciation. The skin was everywhere loose, and even on incision showed no subcutaneous fat. The muscles were atrophied and showed very little rigor mortis; they were pale and thin in appearance. There was no fat in the mesentery or the retroperitoneum. In fact, the absence of fat was so conspicuous that special emphasis was laid on it in the report of the pathologist. The brain nowhere filled the cranium and was from 0.5 to $1 \mathrm{~cm}$. distant from the bony wall of the skull. The dura over it was loose and collapsed, giving the impression that it had been previously distended with fluid. The meninges about the spinal cord were edematous and distended. The eye when removed showed at the macula a deep colored spot about $1.5 \mathrm{~cm}$. in diameter, surrounded by a gray ring $2 \mathrm{~mm}$. wide. The rest of the examination showed nothing of importance to record here.

The child had, therefore, amaurotic family idiocy and pyelitis. She was extremely thin and emaciated, and moved in bed only when disturbed by sound or touch. The amount of muscular activity during the day was so slight that it was almost negligible, except during the colonic convulsions. There was no storehouse of fat on which to draw for energy when desired, as is found in the new-born infant. Although most of the remaining body tissue was muscle, bone and organs, the muscles were thin and atrophic, and could not, therefore, be said to represent normal muscle. Although clinically the actions of this infant were similar to those of the child without any cerebral hemispheres, previously reported by me, ${ }^{1}$ physically the two infants were quite different. In this case there was an almost complete absence of fat, while in the other, the body was composed almost entirely of fat. Table 1 gives the energy metabolism of $B$. D. The length of the periods of observation of this baby and the babies subsequently 1 eported was, in all instances, thirty minutes.

Although the weight of these normal infants is quite close to, and in most instances almost identical with, that of B. D., their length is much shorter and, therefore, they are much fatter. However, they give an idea of what B. D.'s metabolism should have been if the body had been developed normally in relation to the weight. The basal metabolism of B. D., compared to that of three normal infants of the same weight, is very low (approximately 30 per cent. lower than the normal for the weight).

1. Talbot, F. B.: Arch. Pediat., 1915, 32, 452. 
TABLE 1.-Basal Energy Metabolism of B. D.*

\begin{tabular}{|c|c|c|c|c|c|c|c|c|}
\hline \multirow{3}{*}{ Date } & \multirow{3}{*}{$\begin{array}{c}\text { Body Weight and } \\
\text { Surface }\end{array}$} & \multirow{3}{*}{$\begin{array}{l}\text { Height, } \\
\text { Cm. }\end{array}$} & \multicolumn{4}{|c|}{ Heat Produced per 24 Hours } & \multirow{3}{*}{$\begin{array}{l}\text { Average } \\
\text { Pulse } \\
\text { Rate }\end{array}$} & \multirow{3}{*}{$\begin{array}{l}\text { Relative } \\
\text { Activity }\end{array}$} \\
\hline & & & \multirow[b]{2}{*}{$\begin{array}{l}\text { Total } \\
\text { Oals. }\end{array}$} & \multirow{2}{*}{$\begin{array}{c}\text { Per } \\
\text { Kjlo- } \\
\text { gram, } \\
\text { Cals. }\end{array}$} & \multicolumn{2}{|c|}{ Per Sq. Meter } & & \\
\hline & & & & & $\begin{array}{l}\text { Lis- } \\
\text { sauer, } \\
\text { Cals. }\end{array}$ & $\begin{array}{c}\text { DuBois } \\
\text { Linear, } \\
\text { Cals. }\end{array}$ & & \\
\hline \multirow[t]{4}{*}{$12 / 11 / 16$} & \multirow{4}{*}{$\begin{array}{c}6.41 \mathrm{~kg} . \\
10.3 \mathrm{wt}_{2}=- \\
0.355 \mathrm{gq} . \mathrm{m} . \\
\text { Du Boís Linear = } \\
\mathbf{0 . 4 0 8} \text { sq. m. }\end{array}$} & \multirow[t]{4}{*}{76} & $283 \dagger$ & & ... & $\cdots$ & 83 & Active \\
\hline & & & 246 & 38 & 693 & 603 & 83 & Quiet \\
\hline & & & 250 & 39 & 704 & $613 \ddagger$ & 86 & Quiet \\
\hline & & & 250 & 39 & 704 & 613 & 91 & Quiet \\
\hline
\end{tabular}

* One ounce of milk was taken four hours before observations were commenced.

$t$ Preliminary period not used in calculation.

Average respiratory quotient, 0.82. Temperature, rectal, 97 F. beginning of periods: $96.8 \mathrm{~F}$. at end of periods.

TABLE 2.-Comparison of Basal Metabolism of B. D. with That of Normal Infants of Approximately the Same Weight

\begin{tabular}{|c|c|c|c|c|c|c|c|c|c|}
\hline \multirow{3}{*}{ Name } & \multirow{3}{*}{$\begin{array}{l}\text { Age, } \\
\text { Mos. }\end{array}$} & \multirow{3}{*}{$\begin{array}{c}\text { Body } \\
\text { Weight } \\
\text { With- } \\
\text { out } \\
\text { Cloth- } \\
\text { ing, } \\
\text { Kg. }\end{array}$} & \multirow{3}{*}{$\begin{array}{c}\text { Height, } \\
\text { Cm. }\end{array}$} & \multicolumn{4}{|c|}{ Heat Produced per 24 Hours } & \multirow{3}{*}{$\begin{array}{l}\text { Perjods } \\
\text { Aver- } \\
\text { aged }\end{array}$} & \multirow{3}{*}{$\begin{array}{l}\text { Pulse } \\
\text { Rate }\end{array}$} \\
\hline & & & & \multirow[b]{2}{*}{$\begin{array}{l}\text { Total } \\
\text { Cals. }\end{array}$} & \multirow[b]{2}{*}{$\begin{array}{c}\text { Per } \\
\text { Kilo- } \\
\text { gram, } \\
\text { Oals. }\end{array}$} & \multicolumn{2}{|c|}{ Per Sq. Meter } & & \\
\hline & & & & & & $\begin{array}{c}\text { Lis. } \\
\text { sauer, } \\
\text { Cals. }\end{array}$ & $\begin{array}{c}\text { DuBois } \\
\text { Linear, } \\
\text { Cals. }\end{array}$ & & \\
\hline 1. B. D. ......... & 28 & 6.41 & 76 & 249 & 39 & 700 & 610 & $\mathbf{3}$ & 87 \\
\hline $\begin{array}{l}\text { 2. M. C.* (nor- } \\
\text { mal infant)... }\end{array}$ & 4 & 6.17 & 63 & 333 & 54 & 967 & $\cdots$ & 7 & 103 \\
\hline $\begin{array}{l}\text { 3. R. } A_{\text {. }}^{*} \text { (nor- } \\
\text { mal infant)... }\end{array}$ & 7 & 6.42 & 65 & 358 & 56 & 1,002 & ... & 8 & 118 \\
\hline $\begin{array}{l}\text { 4. N. D." (nor- } \\
\text { mal infant)... }\end{array}$ & 7 & 6.79 & 67 & 381 & 56 & 1,032 & ... & 5 & 100 \\
\hline
\end{tabular}

* Benedict and Talbot: Am. Jour. Dis. Child., 1914, 8,, 1.

TABlE 3.-Comparison of Basal Metabolism of B. D. with That of Normal Infants of the Same Age

\begin{tabular}{|c|c|c|c|c|c|c|c|c|c|}
\hline \multirow{3}{*}{ Name } & \multirow{3}{*}{$\begin{array}{l}\text { Age, } \\
\text { Mos. }\end{array}$} & \multirow{3}{*}{$\begin{array}{l}\text { Body } \\
\text { Weight } \\
\text { With- } \\
\text { out } \\
\text { Cloth- } \\
\text { ing, } \\
\text { Kg. }\end{array}$} & \multirow{3}{*}{$\begin{array}{c}\text { Height, } \\
\text { Cm. }\end{array}$} & \multicolumn{4}{|c|}{ Heat Produced per 24 Hours } & \multirow{3}{*}{$\begin{array}{l}\text { Periods } \\
\text { Aver- } \\
\text { aged }\end{array}$} & \multirow{3}{*}{$\begin{array}{l}\text { Pulse } \\
\text { Rate }\end{array}$} \\
\hline & & & & \multirow[b]{2}{*}{$\begin{array}{l}\text { Total } \\
\text { Oals. }\end{array}$} & \multirow[b]{2}{*}{$\begin{array}{c}\text { Per } \\
\text { Kllo- } \\
\text { gram, } \\
\text { Cals. }\end{array}$} & \multicolumn{2}{|c|}{ Per Sq. Meter } & & \\
\hline & & & & & & $\begin{array}{c}\text { Lis. } \\
\text { sauer, } \\
\text { Cals. }\end{array}$ & $\begin{array}{l}\text { DuBois } \\
\text { Linear, } \\
\text { Cals. }\end{array}$ & & \\
\hline 1. B. D......... & 28 & 6.41 & 76 & 249 & 39 & 700 & 610 & 3 & 87 \\
\hline 2. M. R.*... & 25 & 10.96 、 & 79 & 617 & 56 & 1,214 & 1,135 & 3 & 104 \\
\hline \multirow[t]{2}{*}{ 3. Gr. Me.L.*.... } & $261_{4}^{1 / 4}$ & 12.24 & 88 & 605 & 49 & 1,107 & 1,028 & 3 & 96 \\
\hline & $291 / 2$ & 12.82 & 91 & 602 & 49 & 1,101 & 1,025 & 4 & 112 \\
\hline
\end{tabular}

* Not previously reported. 
The metabolism of these normal infants gives an idea of what the metabolism of B. D. would have been had she developed normally for her age. Her total metabolism is less than half that of three average normal infants, and her metabolism per unit of body weight or body surface were both decidedly low.

The metabolism of this amaurotic family idiot is, therefore, very low both when compared to that of normal infants of either the same weight or normal infants of the same age. Her metabolism is comparable to that of J.J. M. who had no cerebral hemispheres, ${ }^{1}$ and, therefore, moved only when stimulated to do so by touch. This child moved both when touched and when disturbed by noise. The body was run at such a low economic level that very little food was necessary for life. ${ }^{1}$

Table 4.-Comparison of Metabolism of Pathologic Children

\begin{tabular}{|c|c|c|c|c|c|c|c|c|}
\hline \multirow{3}{*}{ Name } & \multirow{3}{*}{$\begin{array}{l}\text { Age, } \\
\text { Mos. }\end{array}$} & \multirow{3}{*}{$\begin{array}{l}\text { Body } \\
\text { Weight } \\
\text { With- } \\
\text { out } \\
\text { cloth- } \\
\text { ing, } \\
\text { Kg. }\end{array}$} & \multirow{3}{*}{$\begin{array}{c}\text { Height, } \\
\mathrm{Cm} .\end{array}$} & \multicolumn{4}{|c|}{ Heat Produced per 24 Hours } & \multirow{3}{*}{$\begin{array}{l}\text { Pulse } \\
\text { Rate }\end{array}$} \\
\hline & & & & \multirow[b]{2}{*}{$\begin{array}{l}\text { Total } \\
\text { Cals. }\end{array}$} & \multirow[b]{2}{*}{$\begin{array}{c}\text { Per } \\
\text { Kilo- } \\
\text { gram, } \\
\text { Cais. }\end{array}$} & \multicolumn{2}{|c|}{ Per Sq. Meter } & \\
\hline & & & & & & $\begin{array}{l}\text { Lis- } \\
\text { sauer, } \\
\text { Cals. }\end{array}$ & $\begin{array}{c}\text { DuBois } \\
\text { Linear, } \\
\text { Cals. }\end{array}$ & \\
\hline 1. B. D................ & 28 & 6.41 & 76 & 249 & 39 & 700 & 610 & 87 \\
\hline 2. J. J. M. .............. & 8 & 8.43 & 73.5 & 239 & 28 & 560 & $\cdots$ & 73 \\
\hline 3. Cretin, C. G. ${ }^{2} \ldots \ldots \ldots$... & 44 & 11.83 & 85 & 464 & 39 & 867 & $\ldots$ & 95 \\
\hline
\end{tabular}

The interpretation of the metabolism of B. D. is extremely difficult, as we have a picture of great emaciation, in which a large proportion of the body tissues are muscle with almost no fat. The pulse rate, which, at the time of the observation, was relatively high or normal for the age, ${ }^{3}$ was low at times in the hospital. Under these conditions a high metabolism rather than a low metabolism might have been expected, as has been recorded in the findings of Publication 201 of the Carnegie Institution of Washington. As a matter of fact, the metabolism was very low. The rectal temperature of $97 \mathrm{~F}$. during the period of observation was not an extremely subnormal temperature, but it

2. Talbot, F. B.: Am. Jour. Dis. Child., 1916, 12, 145.

3. In designating the pulse rate of B. D. -83 to 91 , as shown in Table 1as high, or relatively high, it must be remembered that it is not logical to say the pulse rate in a given individual is abnormally high. It has been often pointed out in the Nutrition Laboratory of the Carnegie Institution of Washington, that it is not permissible to argue that a high pulse rate in any given individual absolutely implies a high metabolism. What is more important is the deviation from the normal pulse rate of that individual. 
1s not impossible that this may be an indication of lowered vital activity, although it is quite unreconcilable with the relatively high pulse rate.

In conclusion, this child with amaurotic family idiocy presents a very unusual and complicating situation, in which the metabolism may have been modified either by the subnormal temperature, by emaciation, by the plane on which the baby was living, or by the disease, and does not present any simple explanation. It is hoped that other records of the metabolism of amaurotic family idiots will clear up the doubtful point presented in this picture.

311 Beacon Street. 